\title{
KUALITAS PERPARKIRAN KOTA YOGYAKARTA DARI MULTIPERSPEKTIF
}

\author{
Eddy Kiswanto dan Triyastuti Setianingrum \\ Pusat Studi Kependudukan dan Kebijakan, Universitas Gadjah Mada, Yogyakarta \\ Korespondensi: Eddy Kiswanto (e-mail: eddykiswanto_cpps@ugm.ac.id)
}

\begin{abstract}
Abstrak
Tulisan ini memperlihatkan kepuasan masyarakat terhadap pengelolaan perparkiran yang diselenggarakan Dinas Perhubungan. Penilaian tingkat kepuasan masyarakat dilihat dari berbagai perspektif, yaitu perspektif pengguna parkir, juru parkir (jukir), dan masyarakat di sekitar lokasi parkir. Penilaian nilai indeks menunjukkan semakin tinggi nilai indeks, maka semakin baik pelayanan publik demikian pula sebaliknya. Berdasarkan data, fasilitas di Tepi Jalan Umum (TJU) dan Tempat Khusus Parkir (TKP) dinilai kurang baik. Biaya pelayanan di TJU dinilai tidak baik, sedangkan biaya pelayanan di TKP dinilai kurang baik. Aktivitas parkir di TJU dan TKP dinilai mengganggu oleh masyarakat sekitar lokasi parkir. Aktivitas parkir jugadinilai mengganggu aktivitas lalu lintas, masyarakat, dan menimbulkan kebisingan. Namun, masyarakat sekitar tidak keberatan dengan aktivitas perparkiran. Keberadaan jukir dinilai membantu mengurangi aktivitas parkir yang mengganggu aktivitas lalu lintas tersebut. Nilai Indeks Kepuasan Masyarakat (IKM) terhadap juru parkir (jukir) menunjukkan seragam Jukir dinilai kurang dan aspek pembinaan dinilai relatif baik. Sementara itu, indeks multiperspektif menunjukkan nilai kurang baik.
\end{abstract}

Kata kunci: indeks, Tepi Jalan Umum, Tempat Khusus Parkir, juru parkir

\section{THE QUALITY OF PARKING IN YOGYAKARTA CITY FROM MULTI-PERSPECTIVES}

\begin{abstract}
This paper shows the community's satisfaction of parking management by Department of Transportation and provides inputs to improve the public services' quality. The satisfaction seen from various perspectives, namely the perspective of costumers, the parking officers (jukir), and the community surrounded the parking lot. Assessment of satisfaction level on the index value, where higher values indicate better public services. Survey data indicates that existing facilities at TJU and TKP are still considered inadequate. The cost of services in TJU is categorized bad, while service charge at the location has a bad index value. The parking activity in TJU and TKP is considered as disturbing the community surrounded the parking lot. Parking activity is also considered interfering the traffic activity, community activity, and become the noise. Even so, the surrounding community receives parking activity well. The existence of jukir also is helpful in reducing the parking activity that disrupt the traffic activity. The value of parking officers (jukir) shows from the side of parking facilities that are considered less uniform of jukir and guidance aspects is considered relatively good. Meanwhile, multiperspective index show less good value.
\end{abstract}

Keywords: index, Roadside Public, Special Parking Area, parking officers 


\section{Pendahuluan}

\section{Latar Belakang}

Birokrasi, reformasi birokrasi, dan penciptaan pelayanan publik berkualitas telah menjadi komitmen pemerintah yang dituangkan dalam Undang-Undang Nomor 17 Tahun 2007 tentang Rencana Pembangunan Jangka Panjang Nasional (RPJPN) 20052025, Peraturan Presiden Nomor 5 Tahun 2010 tentang Rencana Pembangunan Jangka Menengah Nasional (RPJMN) 20202014, Peraturan Presiden Nomor 29 Tahun 2010 tentang Rencana Kerja Pembangunan (RKP) 2011, Peraturan Presiden Nomor 81 Tahun 2010 tentang Grand Design Reformasi Birokrasi (GDRB) 2010-2025, Serta Peraturan Menteri Pendayagunaan Aparatur Negara dan Reformasi Birokrasi Nomor 20 Tahun 2010 tentang Roadmap Reformasi Birokrasi (RMRB). Sementara itu, pelayanan publik diatur dengan UU Nomor 25 Tahun 2009 tentang Pelayanan Publik yang segera disusul lima peraturan pemerintah lainnya (yang membahas ruang lingkup, sistem pelayanan terpadu, standar pelayanan, pelayanan berjenjang, dan peran serta masyarakat dalam pelayanan publik). Tata pemerintahan yang baik sangat erat kaitannya dengan reformasi birokrasi, penegakan hukum, peningkatan kualitas pelayanan publik, perubahan pola pikir, pola sikap, dan pola tindak menjadi lebih produktif, efisien, dan produktif. Pelaksana otonomi daerah diharapkan mampu secara optimal membangun bangsa dan negara Indonesia secara terintegrasi, terencana, dan berkelanjutan. Pelaksanaan pemerintahan sekarang bergeser dari "pelaksana" (rowing) ke "pengarah" (steering) menuju tata pemerintahan yang baik, reinventing government dari government ke governance (Komarudin, 2011).
Dalam upaya peningkatan kualitas pelayanan publik, salah satu capaian reformasi birokrasi dan tata kelola pemerintahan didasarkan pada partisipasi masyarakat, dalam hal ini melalui mekanisme survei kepuasan masyarakat. Mekanisme ini dimaksudkan untuk mengetahui tingkat kepuasan masyarakat terhadap penyelenggaraan pelayanan publik. Secara definitif, survei kepuasan masyarakat adalah pengukuran secara komprehensif kegiatan tentang tingkat kepuasan masyarakat yang diperoleh dari hasil pengukuran atas pendapat masyarakat dalam memperoleh pelayanan dari penyelenggara pelayanan publik (Permen Nomor 16 Tahun 2014 tentang Pedoman Survei Kepuasan Masyarakat (SKM) pasal 1). Saat ini pemerintah telah mengeluarkan regulasi terbaru mengenai penyusunan SKM, yaitu melalui Permen PANRB Republik Indonesia Nomor 14 Tahun 2017 tentang Pedoman Penyusunan Survei Kepuasan Masyarakat Unit Penyelenggara Pelayanan Publik.

Dengan penyelenggaraan SKM diharapkan akan diperoleh indeks kepuasan layanan masyarakat atau yang dikenal dengan istilah Indeks Kepuasan Masyarakat (IKM). IKM menjadi salah satu tolok ukur keberhasilan reformasi birokrasi. Pada sisi lain, melalui IKM, instansi penyedia layanan dapat menangkap dan merespons perubahan kebutuhan, persepsi, dan ekspektasi masyarakat terhadap kualitas layanan. Pengukuran IKM juga merupakan salah satu bentuk partisipasi masyarakat dalam mengawasi penyelenggaraan pelayanan publik. Pemerintah Kota Yogyakarta telah melakukan beberapa kali pengukuran IKM. Hal ini berdasarkan Perda Nomor 7 Tahun 2011 tentang Penyelenggaraan Pelayanan Publik dan ditindaklanjuti oleh Pemerintah Kota Yogyakarta mengeluarkan Perwal Nomor 74 Tahun 2014. Perwal tersebut merupakan 
Pedoman Pengukuran Survei Kepuasan Masyarakat di Pemerintah Kota Yogyakarta sebagai pedoman penyusunan SKM. Output dalam kegiatan SKM adalah keluarnya nilai IKM. Sementara itu, IKM dimaknai sebagai tingkat kepuasan masyarakat berdasarkan hasil pengukuran secara kuantitatif dan kualitatif atas pendapat masyarakat dalam memperoleh pelayanan dari penyelenggara dan/atau pelaksana pelayanan publik dengan membandingkan antara harapan dan kebutuhan. Pengukuran IKM yang dilaksanakan Pemerintah Kota Yogyakarta merupakan suatu proses yang secara metodologis terstruktur dan dilakukan untuk menjaring masukan masyarakat berkaitan dengan aspek-aspek pelayanan.

Hasil survei kepuasan masyarakat menjadi bahan bagi Pemerintah Kota Yogyakarta untuk menyusun kebijakan-kebijakan yang dinilai penting dan mendesak untuk meningkatkan kualitas pelayanan kepada masyarakat. Hal itu berarti IKM dapatjuga digunakan sebagai bahan evaluasi kinerja Pemerintah Kota Yogyakarta untuk menetapkan kebijakan lanjutan bagi peningkatan kualitas pelayanan publik di Kota Yogyakarta di masa mendatang. Tulisan ini merupakan penelitian yang dilakukan PSKK UGM bekerja sama dengan Pemerintah Kota Yogyakarta mengenai penilaian masyarakat terhadap pelayanan utilitas kota.

\section{Tujuan}

Studi ini memiliki dua tujuan sebagai berikut.

1. untuk mengukur tingkat kepuasan masyarakat terhadap pengelolaan perparkiran yang diselenggarakan oleh Dinas Perhubungan Kota Yogyakarta

2. memberikan masukan kepada Pemerintah Kota Yogyakarta untuk peningkatan kualitas pelayanan publik.

\section{Tinjauan Pustaka}

Kebijakan pembangunan reformasi birokrasi dilaksanakan dalam rangka meningkatkan tata kelola pemerintahan yang lebih baik dan merupakan bagian terpenting dalam meningkatkan pelaksanaan pembangunan nasional. Kebijakan reformasi birokrasi pada akhirnya diharapkan dapat meningkatkan kualitas pelayanan publik menjadi lebih baik, meningkatkan kapasitas dan akuntabilitas kinerja birokrasi, meningkatkan profesionalisme sumber daya aparatur pemerintah, serta menyelenggarakan pemerintahan yang bersih dan bebas KKN. Birokrasi merupakan institusi yang menggerakkan pembangunan karena tanpa peran birokrasi, pembangunan akan mengalami kemandekan dan justru kehilangan arah. Upaya pemerintah untuk memperbaiki kondisi internal adalah melalui reformasi birokrasi di berbagai bidang strategi, seperti proses rekrutmen pegawai yang ketat, perbaikan kesejahteraan, mekanisme kerja yang transparan, serta adanya reward merit system (memberikan penghargaan dan imbalan sesuai pencapaian prestasi) dan bukannya spoil system (hubungan kerja yang kolutif dan diskriminatif), belum mampu membuat konstruksi birokrasi yang berorientasi kepada pelayanan publik secara efektif dan efisien.

Konteks reformasi didefinisikan sebagai perubahan radikal untuk perbaikan di berbagai bidang dalam suatu masyarakat atau negara. Oleh karena itu, reformasi birokrasi dapat juga diartikan sebagai perubahan radikal dalam bidang sistem pemerintahan. Susunan birokrasi pemerintah bukan hanya diisi oleh birokrat karier, tetapi juga pejabat politik. Menurut teori liberal, birokrasi pemerintah menjalankan kebijakan-kebijakan pemerintah yang mempunyai akses langsung dengan 
rakyat melalui mandat yang diperoleh dalam pemilihan umum. Dengan demikian, birokrasi pemerintah itu bukan hanya diisi oleh para birokrat, tetapi juga terdiri atas bagian-bagian tertentu yang diduduki oleh pejabat politik (Carino, 1994).

Reformasi birokrasi pada hakikatnya merupakanupayamelakukan pembaruanserta perubahan mendasar dan signifikan terhadap sistem penyelengaraan pemerintahan. Hal ini, terutama menyangkut aspek kelembagaan (organisasi), sumber daya manusia aparatur, serta ketatalaksanaan (business process, mekanisme, sistem, dan prosedur) yang berujung pada penciptaan pelayanan publik prima dan berkualitas. Reformasi birokrasi dilaksanakan dalam rangka mewujudkan tata kelola pemerintahan yang baik (good governance/good public governance).

Birokrasi melayani masyarakat (pengguna/ penerima layanan) yang diwujudkan dalam kemudahan pelayanan (baik syarat, prosedur, waktu, biaya, danproduk), pelayananinformasi, pengawasan internal, kepuasan pelanggan, serta penanganan pengaduan masyarakat. Sampara (2000) menegaskan bahwa yang ingin diciptakan dalam pelayanan publik adalah excellent service: self-awareness and esteem, simpathy and enthusiasm, reform, visio and victory, innovative and impressive, care and cooperative, empowerment and evolution. Excellent service tersebut harus didukung oleh birokrat yang memiliki sifat feeling better (merasa lebih baik), getting better (menjadi lebih baik), dan staying better (tetap dalam keadaan lebih baik). Tujuh nilai utama excellent service yang perlu ditegakkan adalah charity (melayani dengan hati nurani), competency, commitment, consistency, care, continuous, dan communication. Dengan kata lain, reformasi birokrasi dan pelayanan publik berusaha membangun aparat negara dan birokrasi yang melayani, profesional, bersih, efektif, efisien, produktif, transparan, akuntabel, dan kredibel.

Masyarakat berhak atas "pelayanan prima" sebagai konsekuensi dari prinsip customerdriven government dalam pelaksanaan reformasi administrasi/pembaruan birokrasi (reinventing government). Dalam bukunya berjudul Mewirausahakan Birokrasi(Reinventing Government) yang terbit tahun 2008, David Osborne dan Ted Gaebler menyarankan adanya penataan dan pembaruan birokrasi pemerintahan secara menyeluruh (reinventing government) dan mewirausahakan birokrasi (enterprising government) dengan membangun aspek berikut ini.

1. pemerintah berorientasi pelanggan (customer-driven government, meeting he needs of the customers, not the bureaucracy)

2. pemerintah berorientasi misi (missiondriven government, transferring ruledriven organization)

3. pemerintah yang tanggap (anticipatory government, prevention rather than cure)

4. pemerintah berorientasi hasil (resultoriented government, funding outcomes, not inputs)

5. pemerintah yang kompetitif (competitive government, injecting competition into service delivery)

6. pemerintah yang berjiwa wirausaha (entreprising government, earning rather than spending)

7. pemerintah yang terdesentralisasi (decentralized government, from hierarchy to participation and teamwork)

8. pemerintah milik masyarakat (communityowned government, empowering rather than serving)

9. pemerintah katalis (cataytic government, steering rather than rowing)

10. pemerintah berorientasi pasar (government oriented marked). 
Pelayanan yang baik hanya akan diwujudkan apabila di dalam organisasi pelayanan terdapat sistem pelayanan yang mengutamakan kepentingan warga negara, khususnya pengguna jasa pelayanan dan sumber daya manusia yang berorientasi pada kepentingan warga negara. Fokus pada kepentingan warga negara merupakan hal yang mutlak dilakukan oleh tiap-tiap unit pelayanan karena keberadaan unit pelayanan publik bergantung pada ada tidaknya warga negara yang membutuhkan jasa pelayanan publik. Oleh karena itu, penyelenggaraan pelayanan publik yang berkualitas telah menjadi tuntutan bagi pemerintah. Kualitas pelayanan adalah suatu kondisi dinamis yang berhubungan dengan produk, jasa, manusia, proses, dan lingkungan yang memenuhi atau melebihi harapan. Kualitas pelayanan juga diartikan sebagai sesuatu yang berhubungan dengan terpenuhinya harapan/kebutuhan pelanggan. Pelayanan dikatakan berkualitas apabila dapat menyediakan produk dan jasa (pelayanan) sesuai dengan kebutuhan dan harapan pelanggan (Goetsch dan Davis, 2002).

Kualitas pelayanan menurut Evans dan Lindsay (2005) dapat dilihat dari berbagai sudut. Jika dilihat dari sudut pandang konsumen, maka kualitas pelayanan selalu dihubungkan dengan sesuatu yang baik/ prima (excellent). Jika kualitas pelayanan dipandang dari sudut product based, maka kualitas pelayanan dapat didefinisikan sebagai suatu fungsi yang spesifik, dengan variabel pengukuran yang berbeda-beda dalam penilaian kualitas sesuai dengan karakteristik produk yang bersangkutan. Kualitas pelayanan jika dilihat dari sudut user based, maka kualitas pelayanan adalah sesuatu yang diinginkan oleh pengguna layanan atau tingkat kesesuaian dengan keinginan pengguna layanan. Sementara itu, jika dilihat dari value based, maka kualitas pelayanan merupakan keterkaitan antara kegunaan atau kepuasan dengan harga. Oleh karena itu, partisipasi pengguna layanan publik sangat penting untuk memberikan penilaian atas pelayanan yang diterimanya.

Partisipasi masyarakat dalam pelayanan publik dikenal dengan konsep co-production. Konsep ini dikenal pertama kali dan dikembangkan sejak tahun 1980-an ketika pakar administrasi publik dan politik urban membangun teori yang menjelaskan kegiatan kolektif dan peran kritis dari keterlibatan warga masyarakat dalam penyediaan pelayanan barang dan jasa. Pada dasarnya teori co-production mengonseptualisasikan pemberian layanan, baik sebagai sebuah penataan maupun proses, yaitu ketika pemerintah dan masyarakat membagi tanggung jawab (conjoint responsibility) dalam menyediakan pelayanan publik (Marschall, 2004). Dengan konsep tersebut, maka tidak dapat dibedakan antara warga masyarakat sebagai pelanggan tradisional dengan pemerintah sebagai penyedia layanan. Kedua pihak dapat bertindak sebagai bagian dari pemberi layanan. Konsep ini sebenarnya memberi ruang untuk dibangunnya inovasi ke dalam partisipasi masyarakat dengan bentuk baru dalam dunia pelayanan publik. Secara teori, co-production dalam pelayanan publik dapat dipahami melalui konsep-konsep pelanggan dan produksi di sektor publik, yaitu consumer produser, regular producer, dan coproduction. Menurut Parks dan Kim (1996), consumer producers adalah pihak yang berhubungan dengan produksi yang pada akhirnya akan menjadi konsumen akhir dari produk yang dibuatnya. Di sisi lain, regular producers adalah yang menyelenggarakan proses produksi, yang akan mengubah output menjadi pembayaran, yang pada akhirnya akan membelanjakannya untuk barang dan 
jasa lainnya. Dalam hal ini co-production memerlukan kedua pihak berkontribusi input pada proses produksi untuk arang dan jasa tertentu. Dengan kata lain, dalam banyak pelayanan, proses produksi output dan outcome memerlukan partisipasi aktif dari penerima layanan barang dan jasa.

Menurut Cooper dan Schindler (2006), partisipasi publik, terutama dalam proses pengambilan keputusan, adalah sarana untuk memenuhi hak dasar sebagai warga. Pada akhirnya tujuan dari partisipasi publik adalah untuk mendidik dan memberdayakan warga. Sementara itu, menurut Marschall (2004), tujuan dari partisipasi publik pada dasarnya adalah untuk mengomunikasikan dan memengaruhi proses pengambilan keputusan sebagaimana juga membantu dalam pelaksanaan pelayanan. Heller, et.al. (1984) menjelaskan adanya dua bentuk dasar partisipasi, yaitu partisipasi akar rumput (grass-root participation) yang mengacu pada organisasi dan gerakan sosial yang didasarkan pada inisiatif warga yang memilih tujuan dan metode mereka sendiri, serta partisipasi mandat pemerintah (governmentmandated participation) yang melibatkan persyaratan hukum bahwa akan ada kesempatan bagi masukan warga terhadap pengambilan keputusan (kebijakan) atau pelaksanaan sebuah lembaga.

Secara sederhana, Cooper dan Schindler (2006) membedakan partisipasi menjadi dua jenis, yaitu partisipasi tidak langsung (indirect participation) dan partisipasi langsung (direct participation). Contoh partisipasi tidak langsung adalah partisipasi masyarakat dalam hal penyelenggaraan negara dengan memilih wakilnya untuk duduk di kursi parlemen. Partisipasi masyarakat dalam peyelenggaraan pemerintah dapat berupa pernyataan pendapat melalui media massa atau disampaikan langsung kepada wakil rakyat. Sementara itu, partisipasi langsung dapat berupa keterlibatan secara langsung warga dalam penyelenggaraan pemerintah, seperti menjadi komisi penasihat, berpartisipasi dalam dengar pendapat, keterlibatan di kelompok-kelompok kepentingan, dan partisipasi dalam lembaga pemerintah yang menyelenggarakan kegiatan pemberian pelayanan umum. Oleh karena itu, partisipasi masyarakat dalam penyelenggaraan pelayanan publik merupakan faktor yang sangat penting untuk memberikan pelayanan publik yang baik. Konsep partisipasi masyarakat terhadap fungsi pelayanan yang diberikan pemerintah dapat berupa partisipasi dalam hal menaati pemerintah, membangun kesadaran hukum, dan peduli terhadap peraturan yang berlaku. Di samping itu, dukungan lainnya dapat juga berupa dukungan nyata dengan membantu secara langsung proses penyelenggaraan pelayanan umum.

Salah satu aspek penting dalam sistem pelayanan publik adalah partisipasi masyarakat. Pemerintah melalui UU Nomor 25 tahun 2009 telah mengakomodasi peran masyarakat dalam pengembangan sistem pelayanan publik yang, antara lain, sebagai bagian dari organisasi penyelenggara, pengguna yang aktif, dan pemangku kepentingan yang memiliki hak untuk mengadu (voice). Selain itu, masyarakat juga ikut terlibat dalam penyusunan standar pelayanan (Dwiyanto, 2010). Partisipasi masyarakat melalui pengaduan terhadap penyelenggaraan pelayanan juga disebutkan dalam Permen PANRB Nomor 13 Tahun 2009 tentang Pedoman Peningkatan Kualitas Pelayanan dengan Partisipasi Masyarakat dalam Rangka Peningkatan Kualitas Pelayanan. Salah satu mekanisme partisipasi masyarakat adalah dengan melakukan survei (Wang, 
2011). Dengan survei tersebut, masyarakat dapat memberikan penilaian terhadap penyelengaraan pelayanan publik yang dilakukan pemerintah.

\section{Metode Penelitian}

Penelitian ini menggunakan metode gabungan (mixed methodology) yang merupakan kombinasi pendekatan kuantitatif dan kualitatif. Hal ini agar diperoleh data yang lebih lebih representatif untuk mengetahui nilai
IKM pengelolaan perparkiran. Pendekatan kualitatif yang digunakan dalam studi ini adalah kajian data sekunder dan focus group discussion (FGD). FGD dilakukan saat penyusunan instrumen penelitian hingga klarifikasi hasil penelitian. Selanjutnya pendekatan kuantitatif dilakukan melalui survei kepada masyarakat pengguna layanan (jukir, masyarakat sekitar lokasi parkir, dan pengguna layanan parkir).

Tabel distribusi populasi dan sampel sebagaimana Tabel 1 berikut ini.

Tabel 1 Populasi dan Sampel

\begin{tabular}{llrr}
\hline \multirow{2}{*}{ Jenis Layanan } & \multicolumn{1}{c}{ Populasi } & Sampel \\
\cline { 2 - 4 } Perparkiran & \multicolumn{1}{c}{ Jenis Data } & \multicolumn{1}{c}{ Jumlah } \\
a. Pengguna & $\begin{array}{l}\text { Pengguna TJU } \\
\text { Pengguna TKP (Senopati dan }\end{array}$ & 3.945 .000 & 391 \\
& $\begin{array}{l}\text { Ngabean) } \\
\text { b. Juru parkir (Jukir) }\end{array}$ & $\begin{array}{l}\text { Juru parkir TJU } \\
\text { c. Masyarakat sekitar }\end{array}$ & $\begin{array}{l}\text { Penduduk Kota Yogyakarta } \\
\text { Lokasi TKP dan TJU }\end{array}$ \\
\hline & Jumlah Sampel & 394.012 & 108 \\
\hline
\end{tabular}

Sumber: Survei IKM Utilitas, PSKK UGM, 2016

Tabel 2 Klasifikasi Nilai Indeks berdasarkan Permen PANRB Nomor 14 Tahun 2017 tentang Pedoman Penyusunan Survei Kepuasan Masyarakat Unit Penyelenggara Pelayanan Publik

\begin{tabular}{ccccl}
\hline $\begin{array}{c}\text { Nilai } \\
\text { Persepsi }\end{array}$ & Nilai Interval (NI) & $\begin{array}{c}\text { Nilai Interval Konversi } \\
(\text { NIK) }\end{array}$ & $\begin{array}{c}\text { Mutu } \\
\text { Pelayanan }\end{array}$ & $\begin{array}{c}\text { Kinerja Unit } \\
\text { Pelayanan }\end{array}$ \\
\hline 1 & $1,00-2,5996$ & $25,00-64,99$ & D & Tidak baik \\
2 & $2,60-3,064$ & $65,00-76,60$ & C & Kurang baik \\
3 & $3,0644-3,532$ & $76,61-88,30$ & B & Baik \\
4 & $3,5324-4,00$ & $88,31-100,00$ & A & Sangat baik \\
\hline
\end{tabular}

Sumber: Permen PANRB Nomor 14 Tahun 2017 
Analisis penelitian menggunakan analisis deskriptif dan data diolah menggunakan perhitungan nilai indeks kepuasan layanan masyarakat. Sementara itu, tahapan yang dilakukan dalam perhitungan indeks adalah sebagai berikut. Langkah pertama adalah memeriksa kualitas data. Kemudian langkah kedua adalah mengonsistenkan pemberian nilai jawaban responden. Langkah ketiga adalah melakukan standardisasi skor nilai dan langkah terakhir adalah melakukan perhitungan indeks.

Setelah nilai indeks diperoleh, maka dilakukan interpretasi nilai indeks yang didasarkan pada Peraturan Menteri Pendayagunaan Aparatur Negara dan Reformasi Birokrasi Republik Indonesia Permen PANRB Nomor 14 Tahun 2017. Permen PANRB membagi nilai indeks ke dalam empat kategori pelayanan, yaitu tidak baik, kurang baik, baik, dan sangat baik (Tabel 2).

\section{Karakteristik Responden}

Responden untuk pelayanan perparkiran terdiri atas beberapa kategori, yaitu pengguna layanan parkir, jukir, dan masyarakat sekitar lokasi parkir. Responden pengguna layanan perparkiran TJU dan TKP sebagian besar berjenis kelamin laki-laki (90,5 persen). Pengguna layanan laki-laki di TKP mencapai 99,6 persen dan di TJU 68,4 persen. Sebagian besar responden TKP berprofesi sebagai kernet bus ataupun supir bus (sektor jasa). Sementara itu, responden masyarakat sekitar lokasi parkir yang berjenis kelamin laki-laki dan perempuan mempunyai persentase yang hampir sama: laki-laki sebesar 55,6 persen dan perempuan 44,4 persen. Dilihat dari pekerjaan responden,
93 persen responden pengguna layanan TKP bekerja di sektor jasa, sedangkan di TJU pekerjaan responden lebih bervariatif. Pekerjaan responden di TJU mulai dari wiraswasta, karyawan swasta, bahkan ada yang tidak bekerja. Mereka yang tidak bekerja sebagian besar adalah ibu rumah tangga dan mahasiswa/pelajar.

Rentang usia responden adalah antara kurang dari 30 tahun hingga lebih dari 45 tahun dan telah menikah. Dilihat dari tingkat pendidikan, responden pengguna layanan, baik di TJU maupun TKP, serta kelompok masyarakat berpendidikan menengah ke atas (SMA ke atas). Tingkat pendidikan responden memberikan pengaruh terhadap ekspektasi mereka terhadap pelayanan. Responden pengguna layanan yang berpendidikan SMA ke atas mencapai 73,2 persen. Secara lebih detail, untuk pengguna di TJU yang berpendidikan SMA ke atas mencapai 92,7 persen dan di TKP mencapai 65 persen, sedangkan untuk kelompok masyarakat mencapai 63,9 persen.

Dalam hal kepemilikan dokumen KTP, hampir sebagian besar responden tidak ber-KTP Kota Yogyakarta. Secara umum, pengguna layanan yang tidak ber-KTP Kota Yogyakarta sebanyak 92,6 persen, sedangkan khusus untuk pengguna TJU sebesar 81,6 persen dan pengguna TKP sebesar 97,1 persen. Meskipun pengguna parkir TJU tidak ber-KTP Kota Yogyakarta, mereka bertempat tinggal di Kota Yogyakarta. Hal ini terlihat dari status pekerjaan responden yang masih pelajar/mahasiswa (kategori tidak bekerja), sedangkan untuk pengguna layanan di TKP, sebagian besar mereka adalah supir/ kernet yang keberadaan di Kota Yogyakarta tidak untuk menetap. Detail karakteristik responden, baik di TJU maupun TKP tampak seperti Tabel 3 berikut. 
Tabel 3 Karakteristik Responden TJU dan TKP

\begin{tabular}{|c|c|c|c|c|c|c|}
\hline \multirow{2}{*}{ Karakteristik } & \multicolumn{2}{|c|}{ Total $(\mathrm{N}=391)$} & \multicolumn{2}{|c|}{ TJU (N=114) } & \multicolumn{2}{|c|}{ TKP (N=277) } \\
\hline & $\mathrm{N}$ & Persen & $\mathrm{N}$ & Persen & $\mathrm{N}$ & Persen \\
\hline \multicolumn{7}{|l|}{ Jenis Kelamin } \\
\hline Laki-laki & 354 & $90,5 \%$ & 78 & $68,4 \%$ & 276 & $99,6 \%$ \\
\hline Perempuan & 37 & $9,5 \%$ & 36 & $31,6 \%$ & 1 & $0,4 \%$ \\
\hline \multicolumn{7}{|l|}{ Status Perkawinan } \\
\hline Kawin & 295 & $75,4 \%$ & 56 & $49,1 \%$ & 239 & $86,3 \%$ \\
\hline Tidak/belum kawin & 94 & $24 \%$ & 57 & $50 \%$ & 37 & $13,4 \%$ \\
\hline Cerai hidup/mati & 2 & $0,5 \%$ & 1 & $0,9 \%$ & 1 & $0,4 \%$ \\
\hline \multicolumn{7}{|l|}{ Usia responden } \\
\hline$<30$ tahun & 114 & $29,2 \%$ & 67 & $58,8 \%$ & 47 & $17 \%$ \\
\hline 30-34 tahun & 34 & $8,7 \%$ & 8 & $7 \%$ & 26 & $9,4 \%$ \\
\hline 35-39 tahun & 71 & $18,2 \%$ & 12 & $10,5 \%$ & 59 & $21,3 \%$ \\
\hline 40-44 tahun & 58 & $14,8 \%$ & 9 & $7,9 \%$ & 49 & $17,7 \%$ \\
\hline$>45$ tahun & 114 & $29,2 \%$ & 18 & $15,8 \%$ & 96 & $34,7 \%$ \\
\hline \multicolumn{7}{|c|}{ Pendidikan Tertinggi yang Ditamatkan } \\
\hline Tidak/belum pernah sekolah & 1 & $0,3 \%$ & 0 & 0 & 1 & $0,4 \%$ \\
\hline Tidak lulus SD & 3 & $0,8 \%$ & 0 & 0 & 3 & $1,1 \%$ \\
\hline SD/MI/SR & 30 & $7,7 \%$ & 2 & $1,8 \%$ & 28 & $10,1 \%$ \\
\hline SMP/MTs & 771 & $18,2 \%$ & 6 & $5,3 \%$ & 65 & $23,5 \%$ \\
\hline SMA/MA/Sederajat & 215 & $55,0 \%$ & 57 & $50 \%$ & 158 & $57 \%$ \\
\hline DI/D2/D3 & 10 & $2,6 \%$ & 4 & $3,5 \%$ & 6 & $2,2 \%$ \\
\hline $\mathrm{D} 4 / \mathrm{S} 1$ & 59 & $15,1 \%$ & 44 & $38,6 \%$ & 15 & $5,4 \%$ \\
\hline S2/S3 & 2 & $0,5 \%$ & 1 & $0,9 \%$ & 1 & $0,4 \%$ \\
\hline \multicolumn{7}{|l|}{ Pekerjaan } \\
\hline Jasa & 265 & $68 \%$ & 7 & $6 \%$ & 258 & $93 \%$ \\
\hline Wiraswasta & 36 & $9 \%$ & 28 & $25 \%$ & 10 & $4 \%$ \\
\hline PNS/BUMN & 7 & $2 \%$ & 5 & $4 \%$ & 2 & $1 \%$ \\
\hline Pensiunan & 4 & $1 \%$ & 4 & $4 \%$ & 0 & 0 \\
\hline Karyawan swasta & 26 & $7 \%$ & 21 & $18 \%$ & 3 & $1 \%$ \\
\hline Tidak bekerja & 53 & $14 \%$ & 49 & $43 \%$ & 4 & $1 \%$ \\
\hline \multicolumn{7}{|l|}{ Ber-KTP Kota Yogyakarta } \\
\hline Ya & 29 & $7,4 \%$ & 21 & $18,4 \%$ & 8 & $2,9 \%$ \\
\hline Tidak & 362 & $92,6 \%$ & 93 & $81,6 \%$ & 269 & $97,1 \%$ \\
\hline
\end{tabular}

Sumber: Survei IKM Utilitas, PSKK UGM, 2016 


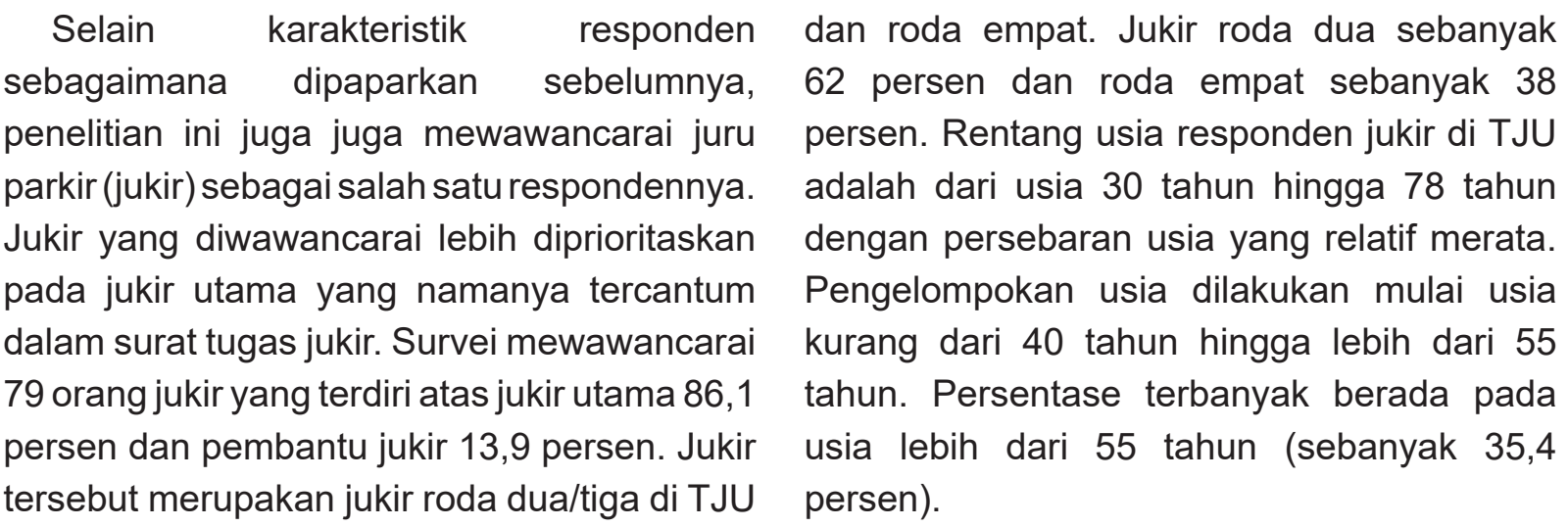

Tabel 4 Karaktertistik Jukir TJU

\begin{tabular}{|c|c|c|}
\hline Indikator & Jumlah & Persen \\
\hline \multicolumn{3}{|l|}{ Usia } \\
\hline$<40$ tahun & 12 & 15,2 \\
\hline 46-45 tahun & 9 & 11,4 \\
\hline 46-50 tahun & 16 & 20,3 \\
\hline $51-55$ tahun & 14 & 17,7 \\
\hline$>56$ tahun & 28 & 35,4 \\
\hline \multicolumn{3}{|l|}{ Jenis Kelamin } \\
\hline Laki-laki & 77 & 97,5 \\
\hline Perempuan & 2 & 2,5 \\
\hline \multicolumn{3}{|l|}{ Pendidikan } \\
\hline Tidak/belum pernah sekolah & 1 & 1,3 \\
\hline Tidak lulus SD & 4 & 5,1 \\
\hline SD/MI/SR & 21 & 26,6 \\
\hline SMP/MTs & 17 & 21,5 \\
\hline SMA/MA/Sederajat & 34 & 43,0 \\
\hline DI/D2/D3 & 2 & 2,5 \\
\hline \multicolumn{3}{|l|}{ Mata pencaharian } \\
\hline Jasa & 8 & 10,0 \\
\hline Wiraswasta & 11 & 14,0 \\
\hline Karyawan Swasta & 5 & 6,0 \\
\hline Petani & 4 & 5,0 \\
\hline \multicolumn{3}{|l|}{ Lama menjadi Jukir } \\
\hline$<5$ tahun & 8 & 10,1 \\
\hline 5-10 tahun & 17 & 21,5 \\
\hline $11-15$ tahun & 16 & 20,3 \\
\hline 16-20 tahun & 15 & 19,0 \\
\hline$>20$ tahun & 23 & 29,1 \\
\hline
\end{tabular}

Sumber: Survei IKM Utilitas, PSKK UGM, 2016 
Jenis kelamin sebagian besar responden jukir adalah laki-laki (97,5 persen) dan hanya 2,5 persen yang berjenis kelamin perempuan (mereka adalah jukir utama kendaraan roda dua). Tingkat pendidikan jukir lebih banyak berpendidikan menengah ke bawah, yaitu SMP/ MTs ke bawah (54,5 persen). Lebih dari separuh responden mengatakan bahwa pekerjaan sebagai juru parkir merupakan pekerjaan utama. Hal ini ditunjukkan lewat pernyataan 65 persen jukir yang tidak memiliki pekerjaan lain selain sebagai jukir. Kurun waktu menjadi jukir bervariasi mulai dari yang di bawah 5 tahun dan lebih dari 25 tahun. Persentase yang lebih dari 25 tahun adalah 29 persen dan antara 5-10 tahun mencapai 22 persen. Sebanyak 72,2 persen responden memiliki KTP Kota Yogyakarta. Secara detail, karakteristik jukir TJU dapat dilihat pada Tabel 4.

\section{Pembahasan}

Pembahasan berikut ini memaparkan beberapa penilaian terkait dengan pelayanan perparkiran yang diselenggarakan oleh Dinas Perhubungan, nilai IKM untuk pengelolaan perparkiran di Tepi Jalan Umum (TJU), nilai IKM untuk pengelolaan perparkiran di Tempat Khusus Parkir (TKP), dan nilai IKM menurut penilaian masyarakat sekitar lokasi parkir, serta nilai komposit IKM untuk pengelolaan perparkiran secara umum. Sebelum pembahasan mengenai nilai indeks sebelumnya, akan dipaparkan penilaian terkait penyelenggaraan pengelolaan perparkiran di Kota Yogyakarta. Pembahasannya akan meliputi fasilitas, pelayanan jukir, pengurusan surat tugas dan pembinaan, penilaian bendel karcis parkir, respons komplain, kepuasan pelayanan Dinas Perhubungan, serta nilai indeks kepuasan layanan perparkiran.
Pelayanan Pengelolaan Perparkiran Kota Yogyakarta

Penilaian pengelolaan perparkiran terkait dengan fasilitas yang diberikan oleh Dinas Perhubungan kepada jukir. Fasilitas tersebut, antara lain, terdiri atas ketersediaan lahan parkir, seragam, topi, dan stick lamp (khusus yang shift malam). Hasil survei memperlihatkan ketersediaan lahan parkir dinilai telah mencukupi (92,4 persen). Sementara itu, fasilitas berikutnya, yaitu fasilitas seragam, menurut pendapat jukir dinilai telah mencukupi oleh 48,1 persen jukir dan tidak mencukupi oleh 51,9 persen jukir. Seragam hanya diberikan kepada jukir utama, sedangkan yang untuk pembantu jukir menjadi tanggung jawab jukir utama. Untuk topi, dinilai telah mencukupi (70,9 persen), sedangkan ketersediaan stick lamp hanya sebanyak 25,3 persen yang menilai telah mencukupi.

Apabila melihat kepadatan kendaraan yang diparkir dibandingkan dengan lahan parkir, sebanyak 26,6 persen jukir menilai tidak padat, yang menilai agak padat sebesar 46,8 persen dan yang menilai padat sebesar 26,6 persen. Hal ini berarti pengaturan kendaraan yang diparkir harus ditata dengan baik karena menurut jukir, lahan parkir dinilai telah mencukupi. Terkait dengan perebutan lahan parkir, menurut jukir, hal itu terjadi, tetapi persentasenya tidak banyak. Sebanyak 11,4 persen responden mengungkapkan perebutan itu jarang terjadi, bahkan 88,6 persen menilai tidak pernah terjadi. Apabila terjadi perebutan lahan, maka yang dilakukan jukir bervariasi, mulai dari tidak melakukan apa-apa (agar tidak terjadi konflik), bermusyawarah untuk pembagian hari kerja/ jadwal parkir, melaporkan ke dinas, hingga mencari lahan parkir baru. 
Penilaian lain terkait dengan aktivitas parkir dibandingkan dengan fungsi yang lain, menurut jukir, aktivitas perparkiran tidak mengganggu kelancaran lalu lintas. Hal ini diungkapkan oleh 91,2 persen responden, sedangkan 8,9 persen menilai agak mengganggu kelancaran lalu lintas. Hal ini berbeda dengan yang dikemukakan pengguna layanan dan masyarakat yang mengatakan bahwa aktivitas perparkiran mengganggu aktivitas lalu lintas. Dapat dimengerti apabila jukir menilai aktivitas perparkiran tidak mengganggu aktivitas yang lain karena parkir merupakan salah satu mata pencaharian bagi mereka.

Penilaian terkait dengan pelayanan jukir menjadi hal yang penting untuk diperhatikan karena jukir merupakan pihak yang memberikan pelayanan langsung kepada pengguna layanan perparkiran. Salah satu bentuk pelayanan yang dilakukan jukir di TJU adalah merespons komplain dari pengguna layanan. Komplain yang disampaikan berkaitan dengan kehilangan kendaraan, kelengkapan kendaraan (misalnya helm dan spion), barang milik pribadi, kerusakan kendaraan, serta aktivitas perparkiran. Kasus yang pernah terjadi adalah kehilangan kelengkapan kendaraan, sedangkan tidak pernah ada komplain dari pengguna layanan terkait kasus kehilangan kendaraan dan barang millik pribadi. Terkait dengan kehilangan kelengkapan kendaraan (helm, spion) pernah dialami oleh 22,8 persen jukir. Tindakan lebih lanjut yang dilakukan oleh jukir adalah dengan mengganti kelengkapan yang hilang, meminta maaf, dan ada pula yang tidak melakukan apapun. Respons terhadap pengaduan atau komplain ini memperlihatkan tingkat responsivitas jukir di menindaklanjuti pengaduan tersebut. Sementara itu, untuk kerusakan kendaraan dan kelengkapan kendaraan, jukir yang pernah mengalaminya hanya sebanyak 2,5 persen saja dan tindak lanjut dari jukir adalah dengan tidak melakukan tindakan apapun.

Kemiringan dalam penataan kendaraan merupakan tugas lain dari jukir dan telah tercantum dalam dokumen surat tugas jukir. Hasil survei menunjukkan dalam penataan roda dua, sebanyak 69,4 persen membentuk 90 derajat, sedangkan yang lainnya membentuk sudut 60 dan 45 derajat. Penataan kendaraan roda dua menurut pengguna layanan diketahui sebanyak 65,8 persen responden menyatakan kendaraannya selalu ditata dalam satu baris. Sementara itu, sisanya menyatakan kendaraannya sering ditata dalam satu baris mencapai 19,3 persen dan 14,9 persen menjawab tidak/jarang ditata dalam satu baris. Penataan kendaraan roda tiga maupun empat lebih banyak yang ditata sejajar maupun miring dengan arah lalu lintas. Pernyataan ini hampir sama dengan pendapat pengguna layanan yang menyatakan bahwa kendaraan roda tiga atau empat sebagian besar dibuat sejajar arah lalu lintas (62,3 persen) dan miring (36 persen), sedangkan yang lainnya tegak lurus (1,8 persen). Dalam penataan kendaraan, hal yang perlu diketahui adalah apakah penataan dalam satu baris ataukah tidak. Berdasarkan hasil survei, menurut 80 persen jukir, kendaraan roda dua ditata dalam satu baris, sedangkan menurut pengguna layanan parkir, dilakukan pada satu badan jalan (33,3 persen). Hal ini berarti yang menyatakan parkir tidak pada satu badan jalan sebanyak 66,7 persen. Penataan kendaraan ini menyesuaikan dengan lokasi parkir yang tersedia dan agar tidak mengganggu aktivitas yang lain.

Dalam melaksanakan tugas sebagai jukir, didasarkan pada surat tugas yang dikeluarkan oleh Dinas Perhubungan. Surat tugas menjadi hal penting yang harus dimiliki seorang jukir karena menunjukkan identitas jukir, termasuk 
lokasi parkir. Survei memperlihatkan bahwa dalam satu tahun terakhir, dari 69 jukir utama sebanyak 60 orang $(75,9$ persen) melakukan pengurusan surat tugas ke Dinas Perhubungan. Mereka melakukan pengurusan surat tugas baru (dua orang) dan surat tugas perpanjangan (58 orang). Proses pengurusan surat tugas baru dinilai mudah, kelengkapan administrasinya juga sedikit, tetapi tidak semua melakukan peninjauan lokasi/tempat parkir saat pengajuan permohonan surat tugas baru. Durasi waktu dari mulai responden mengajukan surat tugas baru hingga peninjauan lokasi memakan waktu tiga minggu. Lama waktu dari peninjauan lokasi hingga turunnya surat juga memerlukan waktu tiga minggu. Kondisi ini perlu menjadi perhatian Dinas Perhubungan karena seharusnya ketika seseorang akan melakukan pengurusan surat tugas baru, ada peninjauan dari dinas mengenai lokasi parkir agar dapat ditentukan potensi parkir yang ada di lokasi tersebut. Terkait dengan lama waktu pelayanan, secara umum waktu yang dibutuhkan untuk keluarnya surat tugas baru adalah antara 6-8 minggu dan hal ini dinilai lama. Selain surat tugas baru, sebagian besar jukir melakukan pengurusan surat perpanjangan. Dalam pengurusan surat perpanjangan, secara prosedur, dapat diurus sendiri oleh jukir maupun diantar oleh petugas. Jukir yang mengurus sendiri sebanyak 23 orang ( 39,7 persen). Selanjutnya 81 persen proses pengurusan perpanjangan surat tugas dinilai mudah dan 19 persen menilai sangat mudah dengan persyaratan yang dinilai sedikit. Lama waktu pelayanan yang dibutuhkan juga relatif lebih cepat, yaitu antara satu hari hingga empat minggu. Menurut jukir, lama waktu pelayanan ini dinilai relatif cepat (72,4 persen) dan sangat cepat (25,9 persen), tetapi ada juga yang menilai kurang cepat (1,7 persen). Seluruh jukir menilai jika mereka tidak pernah ditolak ketika mengajukan perpanjangan surat tugas.

Tanggung jawab Dinas Perhubungan yang harus dilakukan terhadap jukir adalah melakukan pembinaan secara rutin. Dalam satu tahun terakhir, frekuensi pembinaan yang dilakukan Dinas Perhubungan berkisar dari satu hingga enam kali dan menurut jukir, pembinaan paling banyak dilakukan satu hingga dua kali. Frekuensi jukir dalam mengikuti pembinaan juga relatif baik, tetapi sebanyak 19,5 persen jukir tidak pernah mengikuti pembinaan. Pembinaan dilakukan dalambentukceramah, pengarahan/pelatihan, dipanggil ke dinas, serta peninjauan petugas ke lokasi parkir. Dari empat jenis pembinaan kepada jukir, sebagian besar dilakukan di Kantor Dinas Perhubungan Kota Yogyakarta. Pembinaan dengan cara peninjauan langsung ke lokasi parkir tidak sebanyak yang dilakukan di kantor. Pembinaan dilakukan oleh berbagai pihak, yaitu Dinas Perhubungan, polisi, ustaz, pemkot, dan mahasiswa. Pembinaan yang dilakukan telah dinilai tepat (96,7 persen) dan penting (89,9 persen). Pembinaan juga dinilai relatif baik karena beberapa alasan, yaitu menambah wawasan bagi jukir (70 persen), pengarahan jukir terkait tugas dan tanggung jawabnya (18 persen), sertasebagai media kritik/saran maupun komunikasi (masingmasing 6 persen).

Setelah jukir mendapatkan pembinaan dari Dinas Perhubungan, maka menjadi tanggung jawab jukir untuk memberikan pembinaan kepada pembantu jukir. Dari sekitar 68 jukir utama, sebanyak 44,1 persen memiliki pembantu jukir dan 55,9 persen tidak memiliki jukir. Jumlah pembantu jukir yang dimiliki adalah antara satu hingga sepuluh orang. Kemudian sebanyak 63,3 persen jukir utama memiliki satu pembantu jukir, 20 persen memiliki dua pembantu jukir, dan 6,7 persen memiliki dua pembantu jukir. Lainnya ada yang 
memiliki delapan hingga sepuluh pembantu jukir. Salah satu konsekuensi memiliki pembantu jukir adalah melakukan pembinaan terhadap pembantu jukir dan semua jukir utama bersedia memberikan pembinaan tersebut. Pembinaan yang dilakukan oleh jukir utama bervariasi, ada yang melakukannya dalam satu tahun sebanyak satu hingga enam kali. Paling banyak jukir utama melakukan pembinaan sebanyak satu hingga dua kali.

Persoalan mengenai bendel karcis merupakan hal yang perlu mendapat perhatian dari Dinas Perhubungan. Karcis merupakan salah satu bukti pembayaran yang dilakukan oleh masyarakat pengguna jasa parkir. Karcis juga terkait dengan pendapatan Pemerintah Daerah Kota Yogyakarta. Menurut jukir, cara mereka mendapatkan plafon/jumlah bendel disesuaikan dengan potensi parkir yang telah ditentukan Dinas Perhubungan. Semakin berpotensi suatu kawasan parkir akan semakin banyak jumlah bendel yang harus dibelikan, demikian pula sebaliknya. Sebanyak 77,3 persen responden juga menegaskan bahwa jumlah bendel karcis ditentukan oleh Dinas Perhubungan. Jumlah bendel karcis yang ditentukan oleh dinas dibedakan dalam satuan minggu dan bulan. Jumlah bendel karcis yang ditetapkan oleh Dinas Perhubungan berkisar antara 1 hingga 16 bendel dengan durasi waktu habisnya bendel yang berbeda-beda. Jumlah bendel karcis yang habis dipakai dapat dilihat pada Tabel 5 berikut.

Tabel 5 memperlihatkan ada bendel yang jumlahnya dinilai kurang sesuai dengan potensi parkir yang telah ditentukan oleh Dinas Perhubungan. Sebanyak sebelas responden menyatakan jumlah bendel yang ditentukan Dinas Perhubungan adalah dua bendel per bulan, tetapi yang habis dalam satu bulan hanya satu bendel. Plafon jumlah bendel yang paling banyak ditentukan dinas adalah dua bendel dan enam bendel per bulan. Sementara itu, jumlah bendel yang paling banyak habis dalam satu bulan adalah satu dan dua bendel. Hal ini perlu menjadi perhatian Dinas Perhubungan, apakah hal itu karena potensi parkir yang tidak sesuai ataukah karena karcis parkir tidak diberikan kepada pengguna layanan. Menurut jukir, mereka tidak tidak pernah memberikan karcis bekas pakai yang pernah dipakai sebelumnya. Penuturan ini sama dengan

Tabel 5 Perbandingan Jumlah Bendel yang Ditentukan Dinas dan Bendel Habis Terpakai

\begin{tabular}{crrrrrrrrr}
\hline $\begin{array}{c}\text { Jumlah Bendel } \\
\text { yang Ditetapkan } \\
\text { Dinas (bendel) }\end{array}$ & \multicolumn{6}{c}{ Jumlah Bendel Karcis Habis Terpakai (bendel) } & Total \\
\cline { 2 - 7 } $1-3$ & 1 & $\mathbf{2}$ & $\mathbf{3}$ & $\mathbf{4}$ & $\mathbf{8}$ & $\mathbf{1 2}$ & \\
\hline $4-6$ & 14 & 6 & 2 & 1 & 0 & 0 & 27 \\
$7-9$ & 1 & 4 & 0 & 0 & 0 & 1 & 19 \\
$10-13$ & 7 & 1 & 0 & 0 & 1 & 0 & 2 \\
16 & 1 & 0 & 0 & 0 & 0 & 0 & 1 \\
Total & $\mathbf{4 1}$ & $\mathbf{1 1}$ & $\mathbf{2}$ & $\mathbf{1}$ & $\mathbf{1}$ & $\mathbf{2}$ & $\mathbf{5 8}$ \\
\hline
\end{tabular}

Sumber: Survei IKM Utilitas, PSKK UGM, 2016 
yang diungkapkan oleh pengguna layanan. Meskipun terdapat perbedaan jumlah bendel karcis parkir, jukir tidak merasa keberatan dengan jumlah bendel yang telah ditentukan oleh Dinas Perhubungan. Hal ini karena telah sesuai dengan potensi parkir (81,1 persen), sesuai regulasi (15,1 persen), dan sesuai kesepakatan (3,8 persen).

Masih berkaitan dengan karcis parkir, jukir tidak memberikan karcis parkir karena beberapa alasan, yaitu pengguna layanan menolak diberikarcis, pengguna tidak meminta karcis, strategi menambah penghasilan, lupa tidak membawa karcis parkir, lokasi parkir aman, parkir hanya sebentar, menggunakan kartu parkir, dan tidak pernah dicek oleh dinas. Persoalan lain yang juga menarik adalah tidak semua jukir mengetahui besarnya persentase pembagian retribusi. Data survei memperlihatkan sebesar 73,4 persen tidak mengetahui besarnya pembagian retribusi sesuai dengan perda yang berlaku antara jukir dengan pemerintah kota (Dinas Perhubungan). Hanya 26,6 persen yang mengetahui persentase pembagian retribusi tersebut. Mereka yang mengetahui besarnya persentase paling banyak menyebutkan besarnya proporsi adalah 25-75 persen adalah 9 orang dan 40-60 persen adalah tujuh orang. Dari mereka yang mengetahui besarnya pembagian retribusi, 85,7 persen menyatakan setuju dan 14,3 persennya tidak/ kurang setuju.

Terlepas dari ketidaktahuan terhadap besarnya persentase pembagian retribusi, jukir tidak keberatan dengan retribusi yang harus disetor ke Dinas Perhubungan. Sebanyak 93,6 persen responden mengungkapkan ketidakberatannya dan hanya 6,4 persen yang merasa keberatan. Berdasarkan Perda Nomor 18 Tahun 2009 tentang Penyelenggaraan Perparkiran, pasal 19 ayat 2 menyebutkan bahwa besarnya bagi hasil juru parkir di tepi jalan umum adalah maksimal 80 persen dari potensi parkir. Selain setoran resmi, ada pula pungutan lain yang disetorkan selain ke Dinas Perhubungan. Hal ini diungkapkan oleh 3,8 persen yang menyatakan adanya setoran

Tabel 6 Sanksi Dinas Perhubungan Kepada Juru Parkir di TJU

\begin{tabular}{|c|c|c|c|}
\hline Sanksi & $\begin{array}{c}\text { Terlambat } \\
\text { memberikan } \\
\text { setoran (persen) }\end{array}$ & $\begin{array}{c}\text { Terlambat } \\
\text { membeli bendel } \\
\text { karcis } \\
\text { (persen) }\end{array}$ & $\begin{array}{c}\text { Tidak memenuhi } \\
\text { target } \\
\text { (persen) }\end{array}$ \\
\hline $\begin{array}{l}\text { a. Mencabut surat tugas } \\
\text { sebagai jukir }\end{array}$ & 0 & 0 & 2,5 \\
\hline b. Menegur langsung & 21,5 & 17,7 & 15,2 \\
\hline $\begin{array}{l}\text { c. Memberikan peringatan } \\
\text { tertulis }\end{array}$ & 11,4 & 13,9 & 7,6 \\
\hline $\begin{array}{l}\text { d. Memberikan pembinaan } \\
\text { di kantor }\end{array}$ & 2,5 & 1,3 & 0 \\
\hline e. Tidak ada tindakan & 11,4 & 10,1 & 12,7 \\
\hline $\begin{array}{l}\text { f. Mengakumulasi setoran } \\
\text { yang kurang }\end{array}$ & 0 & 0 & 3,8 \\
\hline
\end{tabular}

Sumber: Survei IKM Utilitas, PSKK UGM, 2016 
lain, yaitu ke pengurus RW, RT, dan oknum Pemda Kota Yogyakarta. Ada pungutan yang disetorkan secara rutin dan ada pula yang tidak rutin.

Hal lain yang dikaji dalam penelitian ini adalah sanksi yang diberikan oleh Dinas Perhubungan terhadap jukir. Data survei memperlihatkan tidak jarang jukir terlambat memberi setoran, tidak membeli bendel karcis, ataupun tidak memenuhi target, dan sanksi yang diberikan oleh Dinas Perhubungan atas hal tersebut bervariasi. Tabel 6 menampilkan bahwa sanksi yang paling banyak diberikan adalah memberikan teguran langsung. Selain menegur langsung, dinas juga memberikan peringatan tertulis serta tidak melakukan tindakan apapun. Persentasenya berturut-turut adalah 21,5 persen, 17,7 persen, dan 15,2 persen.

Salah satu aspek yang penting untuk dilihat dalam penyelenggaraan pelayanan adalah respons komplain. Data survei memperlihatkan 27,9 persen jukir pernah menyampaikan kritik/saran meskipun frekuensinya tidak sering dan hanya 1,2 persen yang sering menyampaikannya. Kritik/ saran yang disampaikan adalah mengenai perbaikan pengelolaan parkir dan penyediaan fasilitas parkir. Perbaikan pengelolaan parkir meliputi penataan lahan, sistem perparkiran, alur, akses, tarif parkir, retribusi, pemilihan lokasi dan penertiban atau penambahan perlengkapan jukir (jas hujan), serta pengurangan jumlah setoran retribusi parkir.

Cara menyampaikan kritik dan saran oleh jukir adalah langsung menyampaikan kepada Dinas Perhubungan (39,1 persen) dan melalui forum komunikasi pekerja parkir $(17,4$ persen). Menanggapi kritik dan saran dari jukir tersebut, respons yang diberikan oleh Dinas Perhubungan sangat bervariasi. Respon atau tanggapan tersebut sangat tergantung dari kritik dan saran yang disampaikan sehingga tingkat kepuasan jukir terhadap respons dan tanggapan Dinas Perhubungan juga bervariasi, mulai dari yang memuaskan sampai dengan kurang memuaskan/tidak memuaskan. Tidak banyaknya jukir yang memberikan kritik/ saran disebabkan oleh mereka yang merasa tidak mempunyai masalah dan kualitas pelayanan telah dianggap baik. Alasan yang lainnya adalah responden tidak mengetahui prosedur penyampaian kritik/saran serta pesimis terhadap respons dinas menanggapi komplain yang disampaikan. Sikap pesimis jukir terhadap respons yang akan diberikan Dinas Perhubungan menjadi hal yang perlu dipikirkan lebih lanjut. Hal ini menjadi awal ketidakpercayaan terhadap penyelenggaraaan pelayanan Dinas Perhubungan.

Nilai Indeks Kepuasan Masyarakat di Tepi Jalan Umum (IKM di TJU)

Penilaian untuk pelayanan perparkiran dibedakan untuk pelayanan di Tepi Jalan Umum (TJU) maupun di Tempat Khusus Parkir (TKP). Penilaian terhadap pelayanan di TJU berdasarkan pendapat masyarakat pengguna layanan perparkiran, pendapat juru parkir, dan masyarakat sekitar lokasi perparkiran.

Penilaian berikut ini berdasarkan penilaian responden pengguna layanan perparkiran. Nilai IKM pengelolaan perparkiran di TJU disusun dari beberapa indikator, yaitu biaya pelayanan, dampak aktivitas parkir, fasilitas TJU, dan penyelenggaraan layanan parkir. Dari semua indikator, ada beberapa indikator yang dinilai pengguna layanan perpakiran masuk dalam kategori tidak baik (nilai D), yaitu biaya pelayanan, dampak aktivitas parkir, dan kualitas layanan secara umum. Sementara itu, fasilitas layanan masuk dalam kategori kurang baik (nilai C) dan penyelenggaraan layanan TJU mendapatkan nilai sangat baik (nilai A). Detail nilai indeks dapat dilihat pada Gambar 1 berikut. 


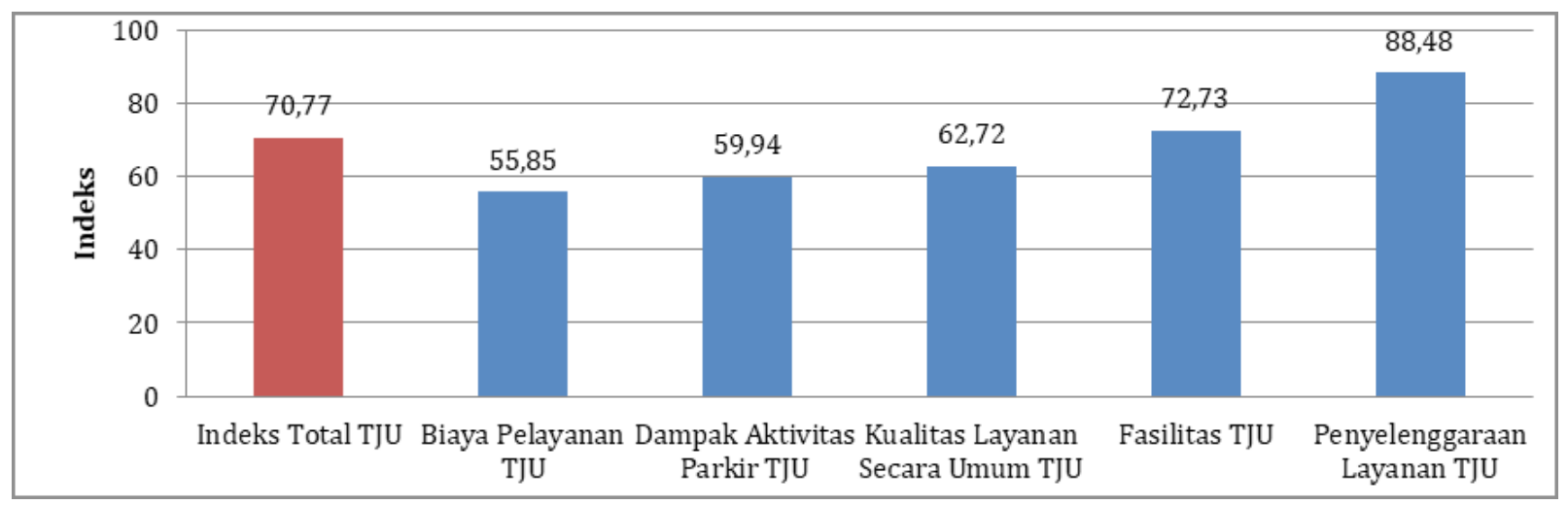

Sumber: Survei IKM Utilitas, PSKK UGM, 2016

Gambar 1 Nilai IKM Pengelolaan Perparkiran di TJU menurut Pengguna Layanan

Aspek biaya pelayanan (retribusi) parkir di TJU memiliki nilai terendah dibandingkan dengan nilai IKM yang lainnya untuk pelayanan perparkiran. Nilai indeks biaya pelayanan TJU terdiri atas beberapa indikator penyusun, yaitu kemahalan biaya TJU, kesesuaikan biaya TJU, dan bukti pembayaran TJU. Kesesuaian biaya TJU memberikan penilaian sejauh mana biaya yang dikeluarkan pengguna layanan sesuai dengan pelayanan yang diterima oleh pengguna layanan.

Selanjutnya kesesuaian biaya pelayanan yang diberikan jukir dinilai kurang baik oleh pengguna layanan TJU (nilai IKM $70,83)$. Demikian juga dengan aspek tingkat kemahalan biaya yang memiliki nilai indeks masuk dalam kategori kurang baik (nilai IKM 69,52). Sementara itu, bukti pembayaran yang dilihat dari penggunaan karcis bekas dan pemberian karcis parkir kepada pengguna layanan memiliki nilai IKM dalam kategori tidak baik (nilai IKM 27,19). Berdasarkan hasil survei, hampir sebagian besar responden tidak mendapatkan karcis parkir dan inilah yang membuat nilai indeks bukti pembayaran masuk dalam kategori tidak baik meskipun penggunaan karcis bekas pakai telah relatif berkurang dibandingkan dengan sebelumnya. Terkait dengan dampak aktivitas parkir, menurut pengguna layanan TJU, hal itu masuk dalam kategori tidak baik (nilai IKM 59,94). Dampak aktivitas parkir dilihat dari seberapa mengganggu keberadaan tempat parkir terhadap aktivitas lalu lintas dan sejauh mana penataan parkir mengganggu aktivitas lalu lintas (baik untuk kendaraan roda dua, roda empat, maupun roda tiga). Penilaian untuk kualitas layanan secara umum memiliki nilai IKM 62,72 (kategori kurang baik). Penilaian ini didasarkan pada tingkat kepuasan secara umum terhadap fasilitas, pelayanan petugas parkir (jukir), dan penyelenggaraan pengelolaan perparkiran di Kota Yogyakarta. Hal tersebut masih memerlukan perhatian dari Dinas Perhubungan, terutama dalam fasilitas parkir.

Penilaian terhadap fasilitas parkir TJU menghasilkan nilai IKM sebesar 72,73 (kategori kurang baik). Beberapa indikator penyusun indeks fasilitas memiliki nilai IKM untuk akses parkir $(68,42)$, keamanan dan kenyamanan TJU $(70,18)$, serta kebersihan tempat parkir $(70,39)$ masuk dalam katagori kurang baik. Sementara itu, penataan parkir TJU $(78,62)$ masuk dalam kategori baik. Dibandingkan dengan indikator lainnya, akses terhadap parkir memiliki nilai indeks terendah. Hal ini berarti kemudahan memperoleh 
tempat parkir masih menjadi persoalan bagi pengguna layanan. Beberapa badan jalan diberi tanda larangan untuk parkir, bahkan parkir hanya boleh pada satu sisi badan jalan. Hal ini yang membuat penilaian akses memiliki nilai terendah dibandingkan dengan yang lain.

Sementara itu, secara umum, nilai IKM berdasarkan penyelenggaraan pelayanan didasarkan pada indikator penggunaan identitas petugas (seperti seragam, topi, maupun stick lamp), jumlah petugas, pelayanan petugas, keramahan petugas, dan pembedaan pelayanan (diskriminasi pelayanan). Nilai IKM untuk penyelenggaraan pelayanan perparkiran yang ada di TJU menunjukkan jumlah petugas dan keramahan petugas TJU masuk dalam kategori kurang baik. Pelayanan petugas TJU masuk dalam kategori baik, sedangkan penggunaan identitas petugas TJU dan diskriminasi pelayanan di TJU masuk dalam kategori sangat baik.

Nilai total IKM penyelenggaraan layanan TJU secara umum adalah 88,48 (sangat baik). Nilai IKM tertinggi untuk indikator penyelenggaraan pelayanan adalah pada diskriminasi pelayanan $(96,27)$ yang berarti tidak ada diskriminasi pelayanan dalam pemberian pelayanan dari jukir. Nilai IKM lainnya yang masuk dalam kategori sangat baik adalah penggunaan identitas $(89,04)$ dan pelayanan petugas di TJU $(84,43)$. Dilihat dari aspek penyelenggaraan pelayanan perparkiran di TJU, nilai yang didapatkan relatif baik. Hal ini perlu dipertahankan, bahkan justru ditingkatkan kembali pelayanannya.

Penilaian berikutnya terkait dengan pelayanan perparkiran berasal dari responden jukir. Penilaian jukir berdasarkan pada pelayanan yang diberikan oleh Dinas Perhubungan. Penilaian itu terdiri atas aspek fasilitas (baik berupa seragam, topi, stick lamp, dan ketersediaan lahan), pembinaan dari Dinas Perhubungan, serta biaya (penilaian terhadap bendel karcis dan sebesar retribusi yang disetorkan ke Dinas Perhubungan). Penilaian nilai IKM jukir adalah 68,76 (kategori baik). Apabila dilihat dari indikator penyusun untuk IKM jukir, nilai indeks pada semua indikator penyusun masuk dalam kategori baik.

Nilai IKM pada indikator pembinaan dari Dinas Perhubungan memiliki nilai tertinggi

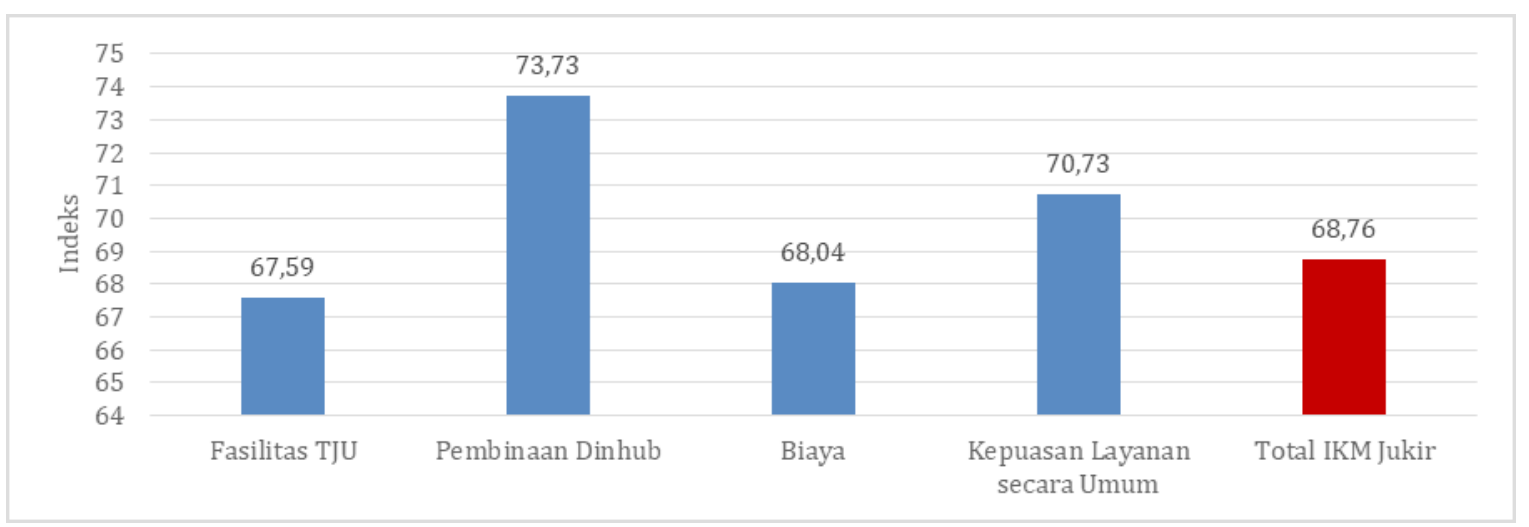

Sumber: Survei IKM Utilitas, PSKK UGM, 2016

Gambar 2 Nilai IKM Pengelolaan Perparkiran di TJU menurut Juru Parkir 
dibandingkan dengan yang lainnya, yaitu 73,73 (kategori baik). Hal ini menunjukkan pembinaanyangdilakukanDinasPerhubungan relatif telah baik dibandingkan dengan tahun sebelumnya. Frekuensi pelaksanaan pembinaan telah rutin dilakukan, sedangkan materi yang disampaikan juga relatif sesuai dengan kebutuhan. Penilaian terkait dengan biaya menyangkut meskipun telah relatif baik, masih membutuhkan perhatian dari Dinas Perhubungan karena masih ada jukir yang tidak mengetahui secara pasti besarnya retribusi yang harus disetorkan ke Dinas Perhubungan sesuai dengan regulasi yang berlaku. Namun, secara umum, jukir juga tidak keberatan dengan penentuan bendel karcis dan besarnya retribusi yang harus disetorkan ke dinas. Hal yang perlu dilakukan Dinas Perhubungan, salah satunya, adalah dengan memberikan pembinaan yang membahas, di antaranya, tentang hak dan kewajiban sebagai jukir. Dengan demikian, diharapkan jukir juga mengetahui secara pasti mengenai hak dan kewajiban mereka sehingga nantinya diharapkan jukir akan dapat memberikan pelayanan kepada pengguna layanan dengan lebih baik lagi.
Nilai Indeks Kepuasan Masyarakat di Tempat Khusus Parkir (IKM di TKP)

Nilai IKM TKP disusun berdasarkan pendapat dari pengguna layanan TKP. Penilaian IKM parkir di TKP meliputi aspek biaya pelayanan, fasilitas, dampak aktivitas parkir, dan penyelenggaraan layanan parkir. Nilai total IKM TKP sebesar 69,10 (kategori kurang baik). Gambar 3 memperlihatkan seluruh nilai IKM TKP dalam kategori tidak baik, kurang baik, dan sangat baik. Nilai IKM TKP yang masuk dalam kategori tidak baik adalah biaya pelayanan $(64,71)$. Fasilitas memiliki nilai indeks 66,74 dan dampak aktivitas parkir 67,60 yang masuk dalam kategori kurang baik. Sementara itu, yang masuk dalam kategori sangat baik adalah penyelenggaraan layanan perparkiran di TKP $(89,73)$. Dari semua indikator penyusun nilai IKM TKP, maka aspek biaya pelayanan TKP memiliki nilai terendah dibandingkan dengan indikator yang lainnya.

Terkait dengan indikator biaya pelayanan, hal yang masih memerlukan perhatian adalah kemahalan biaya dan kesesuaian biaya (kategori tidak baik). Nilai IKM kemahalan

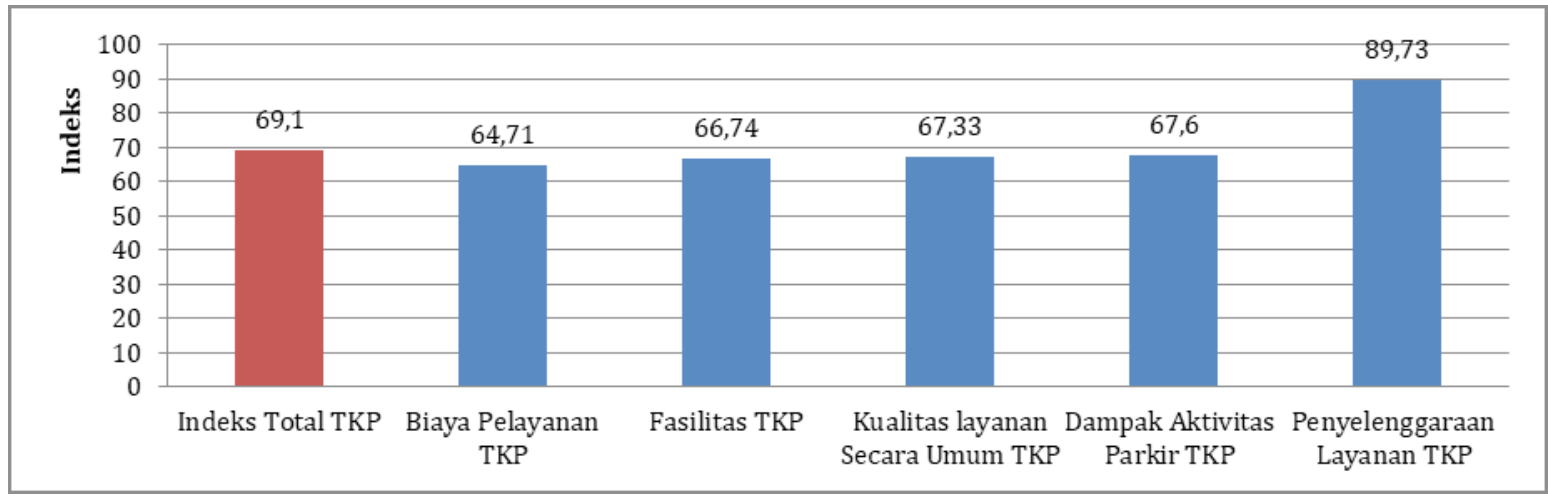

Sumber: Survei IKM Utilitas, PSKK UGM, 2016

Gambar 3 Nilai IKM Pengelolaan Perparkiran di TKP menurut Pengguna Layanan 
biaya TKP sebesar 56 persen (kategori tidak baik). Biaya yang dikeluarkan untuk parkir di TKP didasarkan Perda Nomor 4 Tahun 2012 tentang Retribusi Jasa Usaha. untuk sedan/jeep/pickup/station wagon/box/ kendaraan roda tiga sebesar Rp2.000,00; untuk bus sedang sebesar Rp10.000,00 dan Rp15.000,00; seerta untuk bus besar sebesar Rp20.000,00 dan Rp15.000,00. Tarif ini berlaku untuk dua jam pertama parkir dan untuk setiap jam selebihnya, dikenakan 50 persen dari tarif. Sebagian besar pengguna layanan membayar biaya sebesar Rp50.000,00, bahkan ada yang membayar hingga Rp120.000,00 untuk bus besar. Adanya tarif progresif ini memengaruhi penilaian kemahalan biaya parkir di TKP khususnya bagi bus besar.

Apabila dikaitkan dengan kesesuaian biaya (IKM 62,27), pelayanan jukir TKP masih dirasa kurang karena biaya yang dikeluarkan pengguna layanan TKP dinilai tidak/kurang sesuai dengan pelayanan yang mereka terima. Hal ini memengaruhi nilai indeks kesesuaian biaya. Sementara itu, untuk bukti pembayaran, sebagian besar pengguna layanan mendapatkan bukti pembayaran retribusi. Dengan demikian, penilaian terhadap bukti pembayaran $(75,45)$ mempunyai nilai tertinggi dibandingkan dengan indikator yang lain dan masuk dalam kategori kurang baik.

Terkait dengan persoalan fasilitas di TKP, nilai IKM fasilitas TKP sebesar 66,74 (kategori tidak baik). Indikator penyusun untuk IKM fasilitas menunjukkan penilaian yang tidak baik pada indikator akses parkir $(62,45)$. Hal ini karena pengguna layanan merasakan kesulitan mengakses tempat parkir di TKP. Salah satu sebab kesulitan mengakses lahan parkir TKP adalah karena keterbatasan daya tampung parkir, selain juga karena prioritas parkir lebih bagi kendaraan yang besar (bus) dibandingkan dengan mobil maupun sepeda motor. Penilaian terhadap ketersediaan fasilitas, kebersihan, dan kondisi, meskipun nilainya telah baik, masih memerlukan perhatian dari pemerintah. Kemudian fasilitas yang masih memerlukan perhatian lebih lanjut adalah kamar mandi/WC, fasilitas kebersihan, lokasi/gedung, dan tempat ibadah.

Penilaian lainnya dalam IKM TKP adalah dampak aktivitas parkir dan penilaian kualitas layanan secara umum. Dampak aktivitas parkir dinilai berdasarkan pendapat mengenai sejauh mana keberadaan parkir tersebut mengganggu atau tidak mengganggu aktivitas lalu lintas. Nilai IKM untuk dampak aktivitas parkir adalah 67,6 (kategori kurang baik). Hal ini karena aktivitas perparkiran dinilai agak mengganggu aktivitas lalu lintas. Penilaian terhadap kualitas pelayanan secara umum memiliki nilai indeks sebesar 67,3 (kategori kurang baik). Penilaian kurang baik ini disebabkan oleh rendahnya pelayanan jukir, kepuasan terhadap fasilitas, dan kepuasan pengelolaan perparkiran.

Penilaian terkait dengan penyelenggaraan layanan di TKP memiliki nilai indeks sebesar 89,73 (kategori sangat baik). Penilaian terhadap pelayanan petugas dan diskriminasi pelayanan mempunyai nilai berturut-turut sebesar 94,49 dan 95,67 (kategori sangat baik), sedangkan nilai untuk keramahan petugas adalah 74,28 (kategori kurang baik). Hal ini menunjukkan pelayanan petugas secara umum di TKP relatif baik.

Indeks Kepuasan menurut Masyarakat Sekitar Lokasi

Penilaian terhadap pengelolaan perparkiran juga diambil berdasarkan pendapat masyarakat sekitar lokasi parkir. Hal 


\section{KUALITAS PERPARKIRAN KOTA YOGYAKARTA DARI MULTIPERSPEKTIF}

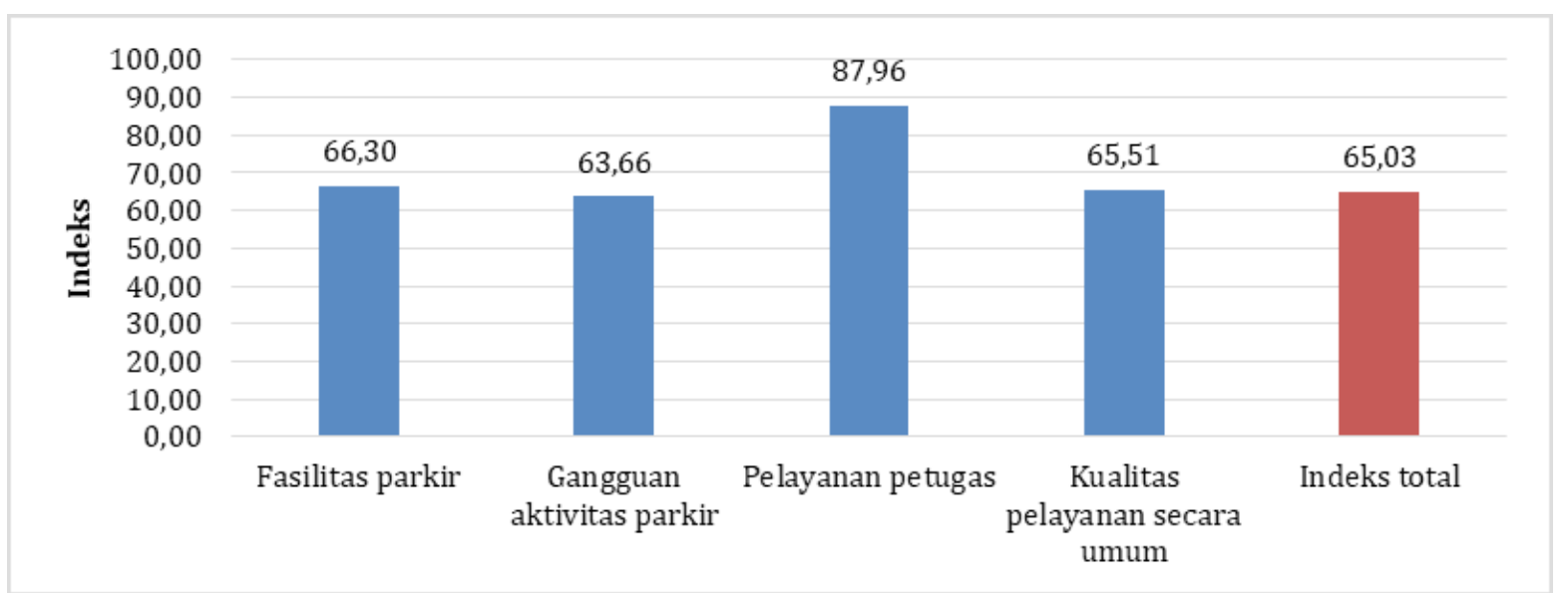

Sumber: Survei IKM Utilitas, PSKK UGM, 2016

Gambar 4 Nilai IKM menurut Masyarakat Sekitar Lokasi

ini perlu dilakukan agar aktivitas perparkiran dapat diidentifikasi mengganggu aktivitas masyarakat atau tidak. Penilaian nilai indeks menurut masyarakat meliputi fasilitas parkir, gangguan adanya aktivitas parkir, dan pelayanan petugas.

Gambar 4 menunjukkan nilai total IKM menurut masyarakat sekitar lokasi parkir adalah 65,03 (kategori kurang baik). Indikator yang lain juga menunjukkan nilai dalam kategori kurang baik dan baik. Sementara itu, indikator yang dinilai baik adalah fasilitas parkir $(66,30)$ dan gangguan aktivitas parkir $(63,66)$, sedangkan pelayanan petugas $(87,96)$ masuk dalam kategori baik. Meskipun semua nilai dinilai telah relatif baik, aspek yang dinilai paling rendah adalah gangguan aktivitas parkir. Hal ini menunjukkan aktivitas perparkiran masih dinilai mengganggu aktivitas lalu lintas dan masyarakat, serta menimbulkan kebisingan. Namun, secara umum, masyarakat tidak keberatan dengan keberadaan aktivitas perparkiran di sekitar mereka. Dinas Perhubungan bertanggung jawab mencari solusi terhadap persoalan yang muncul akibat keberadaan aktivitas perparkiran bagi masyarakat sekitar.
Indeks Komposit Kepuasan terhadap Pengelolaan Perparkiran

Bagian ini memperlihatkan nilai indeks komposit kepuasan pengelolaan perparkiran secara umum baik di TJU maupun di TKP (Gambar 5). Selain itu, nilai indeks juga dibedakan menurut pendapat dari pengguna layanan, masyarakat sekitar, dan Jukir. Nilai IKM jukir hanya didasarkan pada pendapat jukir di TJU sehingga nilai IKM TKP hanya diambil dari pendapat pengguna layanan TKP. Variabel penyusun indeks parkir di TJU adalah variabel biaya pelayanan TJU, dampak aktivitas parkir TJU, kualitas layanan secara umum TJU, fasilitas TJU, dan penyelenggaraan layanan TJU. Sementara itu, indeks pengelolaan parkir di TKP disusun dari variabel biaya pelayanan TKP, fasilitas TKP, kualitas pelayanan secara umum, dampak aktivitas parkir TKP, dan penyelenggaraan layanan TKP. Kemudian IKM juru parkir terdiri atas variabel fasilitas TJU, pembinaan Dinas Perhubungan, biaya, dan kepuasan layanan secara umum. Yang terakhir adalah indeks masyarakat sekitar lokasi parkir yang terdiri atas variabel fasilitas parkir, gangguan aktivitas parkir, pelayanan petugas, dan kualitas pelayanan secara umum. 


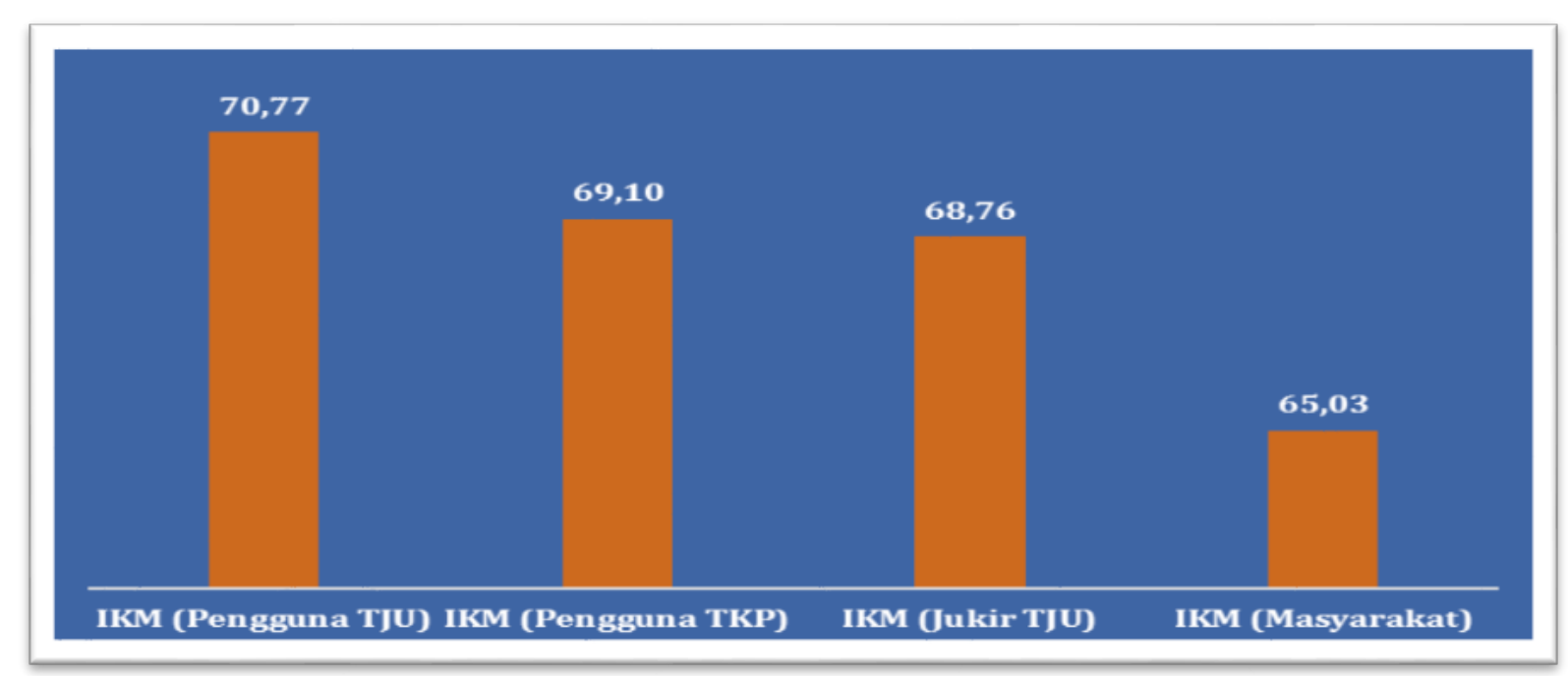

Sumber: Survei IKM Utilitas, PSKK UGM, 2016

Gambar 5 Indeks Kepuasan Layanan Masyarakat Pengelolaan Perparkiran Dinas Perhubungan

Data menunjukkan bahwa secara keseluruhan, nilai IKM pengelolaan perparkiran umumnya masuk dalam kategori kurang baik. Nilai IKM pengelolaan parkir tertinggi berdasarkan pendapat pengguna layanan TJU adalah 70,77 (kategori kurang baik). Nilai terendah IKM berdasarkan pendapat masyarakat sekitar lokasi parkir adalah 65,03 (kategori kurang baik). Keempat nilai IKM masuk dalam kategori kurang baik sehingga perlu menjadi perhatian tersendiri bagi Dinas Perhubungan Kota Yogyakarta untuk meningkatkan pelayanannya (lihat Gambar 5).

\section{Kesimpulan dan Rekomendasi}

Berdasarkan hasil studi yang telah dilakukan terhadap pengelolaan perparkiran yang dikelola Dinas Perhubungan, dapat disimpulkan beberapa hal berikut.

1. Fasilitas yang ada di TJU maupun TKP masih dinilai kurang baik. Hal ini karena beberapa fasilitas, seperti tanda parkir di TJU, dinilai masih kurang. Sementara itu, akses parkir ke TKP dinilai relatif sulit karena prioritas parkir diberikan kepada bus sedang maupun besar dibandingkan dengan mobil dan motor yang tarifnya relatif lebih murah. Selain itu, penyediaan fasilitas di TKP yang dinilai masih kurang adalah kamar mandi, fasilitas kebersihan, dan tempat ibadah.

2. Nilai IKM untuk biaya pelayanan di TJU dinilai tidak baik karena hampir sebagian besar pengguna layanan tidak mendapatkan bukti pembayaran retribusi. Hal ini yang menyebabkan nilai IKM biaya pelayanan di TJU tidak baik meskipun besarnya biaya parkir di TJU secara umum dinilai relatif murah.

3. Biaya pelayanan di TKP memiliki nilai indeks yang kurang baik karena biaya yang dikeluarkan pengguna layanan TKP dinilai relatif mahal. Selain itu, kesesuaian besarnya biaya yang dikeluarkan pengguna layanan dan 
pelayanan yang mereka terima dinilai tidak sesuai.

4. Dampak aktivitas parkir di TJU dan TKP dinilai mengganggu oleh masyarakat sekitar lokasi parkir. Aktivitas parkir dinilai mengganggu aktivitas lalu lintas, aktivitas masyarakat, dan menimbulkan kebisingan. Namun, masyarakat sekitar tidak keberatan dengan adanya aktivitas perparkiran tersebut. Keberadaan jukir juga dinilai dapat membantu mengurangi aktivitas parkir yang mengganggu aktivitas lalu lintas tersebut.

5. Nilai IKM jukir menunjukkan dari sisi fasilitas parkir yang dinilai kurang adalah seragam parkir. Aspek pembinaan yang diberikan Dinas Perhubungan dinilai telah relatif baik, yang dilihat dari sisi frekuensi maupun materi yang disampaikan. Sementara itu, terkait dengan aspek biaya pelayanan, terutama retribusi yang disetor ke dinas, banyak jukir yang tidak mengetahui persentasenya antara jukir dan dinas. Secara umum, mereka tidak keberatan dengan besarnya retribusi maupun bendel karcis yang telah ditentukan oleh dinas.

Berdasarkan hasil studi terhadap pengelolaan perparkiran, maka direkomendasikan beberapa hal sebagai berikut.

1. Dinas Perhubungan perlu lebih mengintensifkan lagi pembinaan kepada jukir, baik dari sisi frekuensi maupun topikpembinaan. Penekanan lebih pada hak dan kewajiban sebagai jukir agar semua jukir memiliki tanggung jawab terhadap pekerjaan mereka. Secara khusus, topik pembinaan, misalnya, terkait dengan penggunaan karcis parkir, regulasi mengenai setoran ke dinas, aspek keamanan, responsivitas terhadap keluhan/masukan dari pengguna layanan, dan kebersihan lokasi parkir.

2. Dinas Perhubungan perlu membuat regulasi mengenai punishment bagi jukir yang tidak mengikuti prosedur yang telah ditentukan, misalnya dengan penunda keluarnya surat tugas parkir. Selama ini punishment tidak diberlakukan kepada jukir yang terlambat memberikan setoran, tidak memenuhi target, maupun terlambat membeli bendel karcis.

3. Fasilitas penunjang, baik di TJU maupun di TKP, perlu ditambah, misalnya tanda-tanda boleh parkir dan seragam. Sementara itu, fasilitas di TKP yang perlu ditambah adalah fasilitas kebersihan, kamar mandi maupun tempat ibadah.

4. Agar aktivitas parkir tidak mengganggu masyarakat sekitar, pemerintah perlu membuat regulasi untuk mewajibkan pertokoan maupun aktivitas ekonomi lainnya, seperti hotel, untuk menyediakan lahan parkir. Regulasi ini dapat menjadi salah satu persyaratan keluarnya perizinan bagi berlangsungnya aktivitas ekonomi tersebut.

5. Masih dijumpai beberapa jukir yang tidak mengenakan seragam parkir, tetapi mengatur aktivitas parkir, bahkan mengatur lalu lintas parkir saat ramai pengunjung. Hal ini memerlukan adanya pelarangan secara tegas terhadap aktivitas tersebut atau jika diperlukan, maka dinas maupun pihak kepolisian perlu melakukan pembinaan. 


\section{Daftar Pustaka}

Obsborne, David dan Ted Gaebler. 2008. Mewirausahakan Birokrasi (Reinventing Government). Jakarta: Teruna Gravika.

Carino, Ledivina V. 1994. Bureucrcy for Democracy, the Dynamics of Executibe Bureucracy Interaction During Governmental Transition. College of Public Administration, University of Philiphines.

Marschall, Melissa J. 2004. Citizen Participation and the Neighborhood Context: A New Look at the Coproduction of Local Publi. Political Research Quarterly; Jun 2004; 57, 2; ProQuest Research Library pg. 231.

Cooper, Donald R. dan Pamela S. Schindler. 2006. Business Research Methods, 9 th Edition. New York: McGraw-Hill/Irwin.

Evans, J.R. and Lindsay. W.M, 2005. The Management and Control of Quality. Sixth Edition. Singapore: Thomson South Western.

Goetsch, David L. and Staanley B. Davis, 2002. Quality Management, Introduction to Total Quality Management for Production, Processing, and Services. New Jersey: Prentice Hall.

Heller, K., Price, R., Reinharz, S., Riger, S., \& Wandersman, A. 1984. Psychology and Community Change: Challenges of the Future. Homewood, IL: Dorsey.

Sampara, Lukman. 2000. Manajemen Kualitas Pelayanan. Jakarta: Penerbit STIA LAN Press.

Park, Chung-Hoon, and Young-Gul Kim. 2006. The Effect of Information Satisfaction and Relational Benefit on Consumers Online Site Commitmennts. Journal of Electronic Commerce in Organizations, Vol. 4, No. 1, Page 70 - 90.

Pusat Studi Kependudukan dan Kebijakan Universitas Gadjah Mada. 2016. Laporan
Penelitian Survei Pengukuran Indeks Kepuasan Layanan Masyarakat di Lingkungan Kota Yogyakarta.

Komarudin, 2011. Reformasi Birokrasi dan Pelayanan Publik. Jurnal Sekretariat Negara RI No. 20 Tahun 2011.

Menteri Pendayagunaan Aparatur Negara dan Reformasi Birokrasi. 2009. Peraturan Menteri PANRB Nomor 13 tahun 2009 tentang Pedoman Peningkatan Kualitas Pelayanan Dengan Partisipasi Masyarakat Dalam Rangka Peningkatan Kualitas Pelayanan. Jakarta.

Wang, Xiaohu. 2001. Assessing Public Participation in U.S. Cities. Public Performance \& Management Review, Vol. 24, No. 4. (Jun., 2001), pp. 322-336. M.E. Sharpe, Inc. 